\title{
PENERAPAN MODEL PEMBELAJARAN KOOPERATIF TIPEGROUP INVESTIGATION (GI) UNTUK MENINGKATKAN MOTIVASI BELAJAR DAN HASIL BELAJAR IPS SEJARAH PADA SISWA KELAS VIII B SMP PGRI 4 DENPASAR TAHUN PELAJARAN 2016/2017
}

\author{
Rulianto \\ Universitas Mahasaraswati Denpasar \\ Email: rulianto35@gmail.com
}

\begin{abstract}
ABSTRAK
Tujuan dari penelitian ini adalah untuk mengetahui manfaat metode pembelajaran kooperatif tipe grup investigasi (GI) dalam meningkatkan motivasi belajar IPS Sejarah pada siswa kelas VIII B SMP PGRI 4 Denpasar dan untuk mengetahui manfaat metode pembelajaran kooperatif tipe grup investigasi (GI) dalam meningkatkan hasil belajar IPS Sejarah pada siswa kelas VIII B SMP PGRI 4 DenpasarHasil penelitian menunjukkan bahwa ada perbedaan nyata. Metode pembelajaran kooperatif tipe Group investigation (GI) dapat di terapkan pada siswa kelas VIII B SMP PGRI 4 Denpasar. metode ini dapat meningkatkan motivasi belajar siswa. hal ini terlihat dari observasi pada siklus I pertemuan I mencapai 28 , 21. pertemuan II 30,0 dan pertemuan III mencapai 30,5, tidak hanya sebatas itu peningkatan juga terjadi pada siklus II Pada pertemuan I di mana hasilnya mencapai 31,39, pertemuan II 34,17 dan pertemuan III 35,25. melihat hasil observasi yang di peroleh artinya antusias siswa dalam mengikuti pembelajaran IPS menjadi semakin baik dengan menggunakan model model pembelajaran. Penerapan model pembelajaran Kooperatif tipe Group Investigation (GI) dapat meningkatkan hasil belajar pada siswa kelas VIII B SMP PGRI 4 Denpasar. Hal ini terlihat pada perbaikan dari segi hasil belajar siswa yang terjadi secara positif, artinya antusias siswa dalam proses pembelajaran pengarah pada pencapaian tujuan pembelajaran dan hasil nilai siswa yang baik, hal ini terlihat pada pelaksanaan tahapan yang peneliti lakukan, di mana pada siklus I mencapai rata rata 82,5\%, daya serap 82,5\% dan ketuntasan belajarnya mencapai $72,5 \%$ dan meningkat pada siklus II menjadi rata rata $86,25 \%$, daya serap $82,25 \%$ dan ketuntasan belajarnya mencapai $100 \%$. peningkatan hasil belajar tidak terlepas kemampuan siswa yang terus di asah di tiap pertemuan. hai ini semakin membuktikan bahwa model pembelajaran yang di terapkan mampu meningkatkan semangat belajar pada mata pelajaran IPS Sejarah, Sehingga dapat disimpulkan bahwa model pembelajaran group investigation mampu meningkatkan motivasi belajar dan hasil belajar siswa.
\end{abstract}

Kata Kunci: Motivasi Belajar, Hasil Belajar, Peningkatan, Group Investigation

\section{ABSTRACT}

The purpose of this research is to know the benefit of cooperative type study type study (GI) method in improving motivation of IPS learning History in grade VIII B students of SMP PGRI 4 Denpasar and to know the benefit of cooperative type study type study (GI) method in improving learning result of IPS History on grade VIII B students SMP PGRI 4 Denpasar The results showed that there is a real difference. Cooperative learning method type Group investigation (GI) can be applied to students of class VIII B SMP PGRI 4 Denpasar. this method can improve students' learning motivation. this is evident from the observation in the first cycle of meeting I reached 28, 21. meeting II 30.0 and meeting III reached 30.5, not only limited to the increase also occurred in cycle II At the meeting I where the result reached 31.39, II 34.17 and meeting III 35.25. see the results of observations that 
are obtained means the enthusiasm of students in following IPS learning becomes better by using model of learning model. Application of cooperative learning model Group Investigation (GI) can improve learning outcomes in students of grade VIII B SMP PGRI 4 Denpasar.This is seen in the improvement in terms of student learning outcomes that occur positively, meaning the enthusiasm of students in the process of instructional learning on the achievement of learning objectives and results of good student value, it is seen in the implementation of the stage that researchers do, where the cycle I to reach the average average $82.5 \%$, absorption $82.5 \%$ and mastery learning reaches $72.5 \%$ and increases in cycle II to average $86.25 \%$, absorption $82.25 \%$ and learning completeness reaches $100 \%$. the increase in learning outcomes is inseparable from the students' ability to continue being taught at each meeting. hai is increasingly proves that the model of learning in applied to improve the spirit of learning in the subjects of IPS History, So it can be concluded that the model study group investigation can improve learning motivation and student learning outcomes.

Keywords: Learning Motivation, Learning Outcomes, Improvement, Group Investigation

\section{PENDAHULUAN}

Pendidikan adalah salah satu bentuk perwujudan kebudayaan manusia yang dinamis dan sarat perkembangan. Pendidikan selalu mengalami pembaharuan atau perubahan dan pembelajaran dari waktu ke waktu selalu mengalami perbaikan dalam rangka mencari struktur kurikulum, sistem pendidikan dan metode pembelajaran yang efektif dan efisien. Perubahan dalam arti perbaikan pendidikan pada semua tingkat perlu terus menerus di lakukan sebagai antisipasi kepentingan asa depan.

Pendidikan yang mampu mendukung pembangunan di masa mendatang adalah pendidikan yang mampu mengembangkan potensi peserta didik sehingga yang bersangkutan mampu memiliki dan memecahkan permasalahan dalam pendidikan yang sedang dihadapinya. Konsep pendidikan tersebut terasa semaki penting ketika seseorang harus memasuki kehidupan di masyarakat dan di dunia kerja, karena yang bersangkutan harus mampu menerapkan apa yang dipelajari di sekolah untuk menghadapi problema yang di hadapi dalam kehidupan sehari hari pada saat ini ataupun yang akan datang.

Menurut Aunurrahman (2010:2) untuk membangun masyarakat terdidik, masyarakat yang cerdas, maka mau tidak mau harus merubah paradigma dan sistem pendidikan. Artinya bahwa paradigma pembelajaran yang sebelumnya lebih menitik beratkan pada peran guru, fasilitator, instruktur, yang demikian besar perjalanannya harus di geser pada pembelajaran yang menekankan peserta didik dalam mengambil inisiatif dan partisipatif dalam kegiatan belajar.

Dalam proses belajar mengajar di kelas, guru pasti di hadapkan pada posisi pembelajaran pada latar belakang etnis, agama, sosio- ekonomi, budaya, tingkah laku dan kemampuan akademik siswa yang beraneka ragam sehingga untuk mencapai keberhasilan dalam pembelajaran bukanlah hal yang mudah untuk di lakukan. Guru di tuntut profesional untuk melaksanakan semua itu. Peran yang di emban oleh guru tidak hanya sekedar mengupayakan agar siswa dapat memperoleh berbagai ragam ilmu pengetahuan dan keterampilan. Akan tetapi lebih dari itu, seorang guru harus 
dapat mendorong siswa untuk dapat bekerja secara kelompok dalam rangka menumbuhkan daya nalar, cara berkikir logis, sistematis, kreatif, cerdas, dan rasa ingin tahu dan dapat menciptakan suasana yang membuat aktif siswa di dalam proses pembelajaran.

Sekolah sebagai suatu institusi atau lembaga pendidikan idealnya harus mampu melakukan edukasi, sosialisasi, dan transformasi. Dengan kata lain, sekolah yang bermutu adalah sekolah yang mampu berperan sebagai proses edukasi dalam kurung proses pendidikan yang menekankan pada kegiatan mendidik dan mengajar. Proses sosialisasi (proses bermasyarakat terutama bagi anak didik), dan wadah proses transformasi (proses perubahan tingkah laku kerah yang lebih baik, atau lebih maju)

SMP PGRI 4 merupakan salah satu sekolah swasta yang mempunyai input atau masukan siswa yang memiliki hasil belajar yang bervariasi, karena hasil belajar yang bervariasi inilah maka peran serta dan keaktifan siswa dalam kegiatan belajar mengajarpun beraneka ragam.

Menurut hasil pengamatan yang dilakukan oleh peneliti melalu observasi kelas dan wawancara dengan guru mata pelajaran sejarah kelas VIII B semester ganjil SMP PGRI 4 Denpasar menunjukkan bahwa pencapaian hasil belajar mata pelajaran IPS, khusunya sejarah sejarah kurang optimal Hal ini disebabkan karena peran serta (keaktifan) siswa dalam kegiatan belajar mengajar sangatminim,Proses belajar mengajar masih berfokus pada guru.Hal ini mengakibatkan kegiatan belajar mengajar lebih menekankan pada pengajaran dari pada pembelajran

Metode pembelajaran yang digunakan di dominasi oleh siswa siswa tetentu saja artinya metode yang diterapkan oleh guru sejarah di kelas VIII B SMP PGRI 4 Denpasar lebih banyak menggunakan metode ceramah sehingga peran serta siswa belum menyeluruh, hal itu menyebabkan diskriminasi dalam kegiatan pembelajaran. Siswa yang aktif atau yang memiliki kompetensi tinggi dalam kegiatan belajar mengajar cenderung lebih aktif dalam bertanya dan menggali informasi dari guru maupun sumber belajar yang lain sehingga cenderung lebih memiliki pencapaian kompetensi belajar yang lebih tinggi. Sedangkan siswa yang kurang aktif cenderung pasif dalam KBM, mereka hanya menerima pengetahuan yang datang padanya sehingga memiliki pencapaian kompetensi belajar yang lebih rendah dan akan sulit untuk beradaptasi sehingga hal itu semakin membuat mereka tertinggal dari siswa siswa yang aktif. Slavin (dalam Trianto 2010:56). Untuk menghindari hal tersebut, guru harus mampu menciptakan lingkungan belajar yang alamiah.

Proses pembelajaran berlangsung alamiah dalam bentuk kegiatan siswa bekerja dan mengalami, bukan mentransfer pengetahuan dari guru ke siswa. dalam hal ini belajar akan lebih bermakna jika anak mengalami apa yang dipelajarinya, bukan mengetahuinya. Pembelajaran yang berorientasi pada penguasaan materi terbukti berhasil dalam kompetisi mengingat jangka pendek tetapi gagal drama membekali anak memecahkan persoalan jangka panjang.

Berdasarkan pertimbangan di atas maka perlu dikembangkan suatu metode pembelajaran yang mampu menciptakan lingkungan belajar yang alamiah yaitu mampu melibatkan peran serta siswa secara menyeluruh sehingga kegiatan belajar mengajar tidak hanya di dominasi oceh 
siswa tertentu saja. Selain itu, melalui proses dan pemilihan metode pembelajaran tersebut di harapkan sumber belajar atau informasi yang diterima siswa tidak hanya dari guru melainkan siswa aktif mencari Sauber belajar yang lain untuk menambah wawasan tingkat ilmu pengetahuannya terutama pada mata pelajaran IPS sejarah. Dengan dana sumber belajar khusus IPS sejarah ini, di harapkan dapat memberikan pengaruh yang signifikan guna untuk meningkatkan motivasi belajar siswa yang nantinya mempengaruhi peningkatan hasil belajar.

Salah satu metode pembelajaran yang melibatkan peran serta siswa adalah Kooperatif. Strategi pembelajaran in9i merupakan suatu bentuk inovasi untuk dapat menciptakan situasi pembelajaran yang menantang dan menyenangkan agar dapat meningkatkan prestasi belajar siswa. dalam model pembelajaran kooperatif lebih menitiberatkan pada proses belajar dengan kelompok dan bukan mengerjakan sesuatu bersama kelompok. Proses belajar dalam kelompok akan membantu siswa menemukan dan membangun sendiri pemahaman mereka tentang materi pelajaran yang tidak dapat di temui pada metode konvensional.

Menurut Aunurahman (2010:140) keberhasilan proses belajar tidak terlepas dari kemampuan guru mengembangkan model model pembelajaran yang berorientasi pada peningkatan intensitas keterlibatan siswa secara efektif di dalam proses pembelajaran. Pengembangan model pembelajaran yang tepat pada dasarnya bertujuan untuk menciptakan kondisi pembelajaran yang memungkinkan siswa dapat belajar secara aktif dan menyenangkan sehingga siswa dapat meraih hasil belajar dan prestasi yang optimal.
Sebagaimana lazimnya keberhasilan suatu proses pembelajaran selain di dukung oleh fasilitas yang baik, kualitas pendidikan yang memenuhi kualifikasi, salah satu hal yang di anggap penting adalah peran aktif siswa dalam proses pembelajaran tersebut. Peran aktif siswa di sini tentunya di awali dengan adanya motivasi untuk mempelajari suatu materi pelajaran metode belajar yang di pergunakan oleh guru akan sangat berpengaruh pada motivasi terhadap hasil belajar siswa. jika metode yang di gunakan sudah tepat dan sesuai dengan situasi dan kondisi siswa, maka akan muncul motivasi siswa untuk belajar.

Metode pembelajaran kooperatif tipe GI merupakan model pembelajaran yang memiliki kelebihan di mana melatih para siswa berpartisipasi dalam pengembangan sistem sosial dan memulai pengalaman, secara bertahap, belajar bagaimana menerapkan metode ilmiah untuk meningkatkan kualitas masyarakat. model grup investigasi merupakan bentuk pembelajaran yang mengombinasikan dinamika proses demokrasi dengan proses inkuiri akademik. Selain siswa belajar pengetahuan akademik mereka juga terlibat dalam permasalahan pemecahan masalah sosial. Dengan demikian kelas harus menjadi miniatur demokrasi yang menghadapi masalah masalah dan melalui pemecahan masalah, memperoleh pengetahuan dan menjadi sebuah kelompok sosial yang lebih efektif.

\section{METODE PENELITIAN}

Peneliti melakukan penelitian dengan menggunakan model Kurt Lewin yang terdiri dari dua siklus, setiap siklus terdiri dari tiga kali pertemuan yaitu dua kali tatap muka dan satu kali evaluasi. Setiap siklus terdiri dari empat tahapan yaitu (1) perencanaan, (2) tindakan, (3) observasi, 
(4) refleksi (Kunandar, 2018:42). Penelitian ini tidak hanya melibatkan peneliti dengan siswa saja, namun juga melibatkan guru IPS Searah Kelas VIII B SMP PGRI 4 Denpasar.

\section{Siklus I}

Siklus I dalam penelitian ini terdiri dari 4 tahapan yaitu sebagai berikut :

1. Perencanaan

Perencanaan dalam penelitian tindakan kelas sangat penting untuk dilakukan, hal ini diperlukan untuk mengatur merancang apa saja yang akan di lakukan. Aspek aspek yang perlu disiapkan yaitu :

(1) berdasarkan permasalahan yang muncul pada refleksi awal, maka peneliti bersama guru merancang tindakan yang akan di lakukan melalui model pembelajaran kooperatif tipe Group investigasi (GI).

(2) membuat kesepakatan bersama guru bidang studi IPS Sejarah untuk menetapkan materi yang di ajarkan.

(3) merancang program pembelajaran yang berupa rencana pelaksanaan (RPP) serta lembar pengamatan untuk penilaian aktivitas siswa.

(4) menyusun tes kuis untuk tiap pertemuan pada siklus I yang sesuai dengan materi yang di ajarkan.

(5) menyusun tes prestasi belajar untuk akhir siklus I sesuai dengan materi yang telah di ajarkan.

\section{Tindakan}

Dalam pelaksanaan tindakan ini satu siklus terdiri dari empat kali pertemuan di mana tiga kali pelaksanaan proses pembelajaran diskusi dan satu kali evaluasi. adapun pelaksanaan tindakan pada setiap pertemuan adalah sebagai berikut :

\section{Pertemuan 1.1}

(1) Menginformasikan kepada siswa tentang tujuan pembelajaran (indikator) yang ingin di capai sesuai dengan perencanaan pembelajaran, rencana kegiatan yang akan siswa kerjakan berdasarkan model pembelajaran GI. serta menyajikan informasi yang berkaitan dengan materi pembelajaran dengan cara demonstrasi lewat bahan bacaan.

(2) siswa di bagi menjadi beberapa kelompok, yang asing asing beranggotakan 5-6 orang. pembentukan kelompok di lakukan berdasarkan penggabungan jenis kelamin, kemampuan rata rata siswa dan agama yang dianut.

(3) peneliti membagikan lembar tugas yang harus di kerjakan oleh siswa.

(4) memasuki kegiatan inti, masing masing kelompok mengerjakan topik topik yang telah di pilih untuk di selidiki atau di investigasi dengan mengkaji dari berbagai sumber.

(5) peneliti secara kolaboratif dengan guru IPS Sejarah mengamati secara cermat kegiatan siswa dalam proses pembelajaran berdasarkan lembar observasi yang telah di siapkan

(6) setiap kelompok mempresentasikan hasil kerja kelompok di depan kelas dan siswa yang lain menyimak dan menanggapi hasil kerja dari kelompok yang presentasi.

(7) pada hasil diskusi, peneliti memberikan kesimpulan dari hasil kerja tiap kelompok.

\section{Pertemuan 1.2}

Pertemuan 1.2 dilaksanakan dengan menggunakan langkah langkah pelaksanaan 
yang tidak jauh berbeda dengan pelaksanaan tindakan pada pertemuan sebelumnya dengan menggunakan metode Group Investigation (GI)

\section{Pertemuan 1.3}

Pertemuan 1.3 dilaksanakan dengan menggunakan langkah langkah pelaksanaan yang tidak jauh berbeda dengan pelaksanaan tindakan pada pertemuan sebelumnya dengan menggunakan metode Group Investigation (GI)

\section{Pertemuan 1.4}

pada pertemuan ini di laksanakan tes prestasi belajar secara tertulis, sesuai mari yang telah di ajarkan pada siklus 1 yaitu pada pertemuan 1,2 dan 3 . hasil dari tes prestasi ini di jadikan acuan untuk mengetahui tingkat tes prestasi belajar siswa.

3. Observasi

Observasi sebagai alat penelitian banyak di gunakan untuk mengukur tingkah laku individu ataupun proses terjadinya suatu kegiatan yang di amati. tahap ini di lakukan pada saat pelaksanaan tindakan berlangsung dan di amati oleh guru kolaboratif dengan peneliti. melalui observasi dapat di ketahui bagaimana sikap dan prilaku siswa dan yang di amati di sini menyangkut motivasi belajar siswa yang meliputi kesiapan belajar siswa, tanggapan siswa terhadap penjelasan guru dan aktivitas siswa dalam belajar kelompok.

\section{Refleksi}

Tahap refleksi ini dilaksanakan setelah proses pembelajaran pada siklus I dengan pemberian tes tertulis pada siswa. proses refleksi ini memegang Raman penting dalam menentukan suatu keberhasilan penelitian tindakan kelas. tujuannya untuk melihat kendala maupun kekurangan kekurangan yang di alami siswa saat tindakan berlangsung dengan menggunakan model pembelajaran kooperatif tipe Group investigation (GI). dengan adanya evaluasi tersebut dapat di jadikan bahan perbaikan oleh peneliti pada pelaksanaan siklus berikutnya.

\subsubsection{Siklus II}

Siklus II dilaksanakan untuk menindak lanjuti kendala, hambatan, dan kekurangan kekurangan yang di temukan atau di hadapi pada saat siklus I. Pada saat pelaksanaan siklus II ini juga terdiri dari 4 tahapan yaitu (1) perencanaan, tindakan, (3) observasi dan (4) refleksi. Sedangkan untuk aspek aspek yang di siapkan sama halnya dengan siklus I, begitu halnya pada saat tahap tindakan yang terdiri dari tiga pertemuan, dua kali pertemuan diskusi dan satu kali pertemuan untuk evaluasi. Pada tahap siklus II ini mengulangi tahap siklus I sampai dengan permasalahan dalam penelitian terselesaikan.

\section{HASIL DAN PEMBAHASAN}

\section{Penerapan Metode Pembelajaran Kooperatif Tipe Group Investigation (GI) Dapat Meningkatkan Motivasi Belajar Ips Sejarah Pada Siswa Kelas VIII B SMP PGRI 4 Denpasar}

Pelaksanaan pembelajaran dengan menggunakan metode pembelajaran kooperatif tipe grup investigasi memiliki langkah langkah dalam pelaksanaannya di antaranya adalah sebagai berikut :

1) Seleksi Topik para siswa memilih berbagai sub topik dalam suatu wilayah masalah umum yang biasanya di gambarkan lebih dahulu oleh guru. selanjutnya para siswa di organisasikan ke 
dalam kelompok kelompok yang asing asing kelompok berorientasi pada tugas yang beranggotakan 2-6 orang, kombinasi kelompok heterogen baik dam jenis kelamin etnik maupun akademis.

2) Merencanakan kerja sama

para siswa beserta guru merencanakan berbagai prosedur belajar khusus, tugas dan tujuan umum yang konsisten dengan berbagai topik dan sup topik yang telah di pilih pada langkah pertama.

3) Implementasi

para siswa melakukan rencana yang telah di rumuskan pada langkah kedua. pembelajaran harus melibatkan berbagai aktivitas dan keterampilan dengan berbagai variasi yang luas dan mendorong para siswa untuk menggunakan berbagai sumber, baik yang terdapat di dalam maupun di luar sekolah. guru secara terus menerus mengikuti kemajuan tiap kelompok dan memberikan bantuan jika di perlukan.

4) Analisis dan sintesis

para siswa menganalisis dan menyintesiskan berbagai informasi yang di peroleh pada langkah ketiga dan merencanakan agar dapat di ringankan dalam suatu penyajian yang menarik di depan kelas.

5) Penyajian hasil akhir semua kelompok menyajikan suatu persentase yang menarik dari berbagai topik yang telah dipelajari agar semua siswa dalam kelas saling terlibat dan mencapai suatu perspektif yang luas mengenai topik yang di bahas. sedangkan persentase kelompok di koordinir oleh guru.
6) Evaluasi

Guru beserta siswa melakukan evaluasi mengenai kontribusi tiap kelompok terhadap pekerjaan kelas kelas sebagai suatu keseluruhan. evaluasi dapat mencakup tiap siswa secara individual ataupun kelompok.

Dalam penelitian ini siswa yang di libatkan sebagai subjek penelitian secara keseluruhan berjumlah 28 orang yang terdiri dari 17 orang siswa laki laki dan 11 orang siswa perempuan. dan di lihat dari ebi agama sebagian mereka beragama islam yakni 14 orang, beragama hindu yakni 11 orang dan sisanya beragama katolik.

Berdasarkan paparan di atas meskipun tampak keberagaman tersebut tidak terlalu tampak variatif dari jumlah kategori etnis. namun karakteristik tersebut telah memenuhi salah satu aspek dari kriteria yang di harapkan dalam model pembelajaran kooperatif tipe grup investigasi yakni pembentukan kelompok sebagai wujud dari pembelajaran kooperatif sebaiknya bersifat pluralistik atau heterogen baik dari jenis kelamin, ras/etnis, agama maupun kemampuan akademik.

Sesuai dengan hasil wawancara menunjukkan bahwa model yang peneliti terapkan ini dapat membangkitkan rasa senang memotivasi siswa untuk belajar. seperti yang di kemukakan oleh sua orang siswa yaitu adinda saputri yang mengatakan bahwa bila di bandingkan dengan cara belajar IPS sejarah yang dulu, Cara belajar yang 
sekarang di rasa lebih menyenangkan, saya lebih mengerti pelajaran dan bersemangat mengikutinya, selanjutnya oktavianus mengatakan bahwa "sejak belajar menggunakan metode ini, kami menjadi tidak takut untuk mengeluarkan ide ide kami, selain itu kami belajar dengan sesama teman dengan situasi yang santai dan tidak merasa tertekan.

Tabel 4.9 Motivasi belajar IPS Sejarah pada siklus I dan Siklus II

\begin{tabular}{|c|c|c|c|c|c|}
\hline \multicolumn{6}{|c|}{ Hasil Observasi } \\
\hline & Siklus I & & & Siklu & \\
\hline I & II & III & I & II & III \\
\hline 28,21 & 30,0 & 30,5 & 31,39 & 34,17 & 35,25 \\
\hline
\end{tabular}

Bila di bandingkan dengan data pada kedua siklus, maka terlihat bahwa terjadi peningkatan positif di setiap pertemuan dari siklus I sampai pada siklus II. di mana pada siklus I pertemuan pertama dengan rerata 28,21 meningkat menjadi 30,0 pada pertemuan kedua meningkat lagi menjadi 30,5 pada pertemuan ketiga. pada siklus II pertemuan pertama dengan rerata 31,39 meningkat pada pertemuan kedua menjadi 34,17 dan meningkat lagi pada pertama ketiga menjadi 35,25.

Berdasarkan data di atas semakin membuktikan bahwa proses belajar siswa menjadi lebih efektif, selanjutnya motivasi siswa dalam kerja sama kelompok juga semakin tinggi yaitu di lihat dari semangat siswa untuk menyampaikan pendapat dan argumentasinya menjadikan siswa menjadi lebih berani. Ham ini dapat di simpulkan bahwa terjadi perubahan motivasi belajar pada siswa kelas VIII B SMP PGRI 4 Denpasar.

\section{Penerapan Model Pembelajaran Kooperatif Tipe Grup Investigasi Dapat Meningkatkan Hasil Belajar IPS Sejarah Pada Siswa Kelas VIII B SMP PGRI 4 Denpasar.}

Meskipun pembelajaran kooperatif d atur dalam wujud pembelajaran yang berorientasipada kelompok namun penilaian akhir atau indikator keberhasilan tetap di tujukan untuk mengetahui penguasaan siswa terhadap materi atau kompetensi dasar yang harus di capai dalam pembelajaran di sekolah secara individu. penilaian hasil belajar siswa seperti telah di paparkan pada paparan hasil penelitian di atas mengacu pada dua aspek yakini penilaian tes secara berkelompok dan tes individu yang di lakukan tiap selesai tatap muka pada akhir siklus.

Data mengenai hasil belajar dengan tes individu, mempelihatkan dengan jelas bahwa hasil belajar siswa mengalami peningkatan pada tiap siklus. berdasarkan hasil analisis seperti pada tabel 4.4 dapat di ketahui bahwa pada siklus I di peroleh rata rata 82,5 dengan daya serap $82,5 \%$ dan ketuntasan belajar $72,5 \%$ yang tergolong pada klasifikasi cukup baik pada siklus I. rendahnya hasil belajar pada siklus I disebabkan karena siswa selalu di hadapkan pada sistem pembelajaran ceramah yang membuat siswa menjadi jenuh.

Dengan mengikuti proses pembelajaran kooperatif tipe grup investigasi yang di terapkan oleh peneliti, menjadikan siswa banyak yang mengalami kebingungan karena belum terbiasa. pada saat belajar kelompok siswa terlihat tidak 
memanfaatkan diskusi dengan baik, di mana masih banyak siswa yang ribut dalam melakukan diskusi sehingga konsep mengenai materi yang di diskusikan kurang optimal. sebagian besar siswa dalam belajar kelompok juga belum berani untuk mengajukan pendapat ataupun bertanya baik dengan kelompok maupun guru. sedangkan pada siklus II seperti yang di tunjukkan pada tabel 4.7 di mana mencapai rerata 86,25 dengan daya serap $86,25 \%$ dan ketentuan belajar mencapai $100 \%$ dan tergolong ke dalam klasifikasi baik. dengan demikian pada siklus II terjadi peningkatan dan seluruh siswa telah mencapai kriteria ketuntasan minimal (KKM) pada mata pelajaran IPS Sejarah.

Demikian juga dengan skor kelompok mengalami peningkatan, pada saat menggunakan metode pembelajaran (GI) siklus I dengan nilai rata rata 69,10 pada pertemuan kedua dengan nilai rata rata 71,96 dan pertemuan ketiga nilai erat rata tetap 71,96 . pada siklus II pertemuan pertama dengan nilai rata rata 76,07 Meningkat pada pertemuan kedua dengan nilai rata rata 80 dan pertemuan ke tiga dengan rata rata meningkat lagi menjadi 83,03. ini artinya peningkatan rata rata kelompok berada pada taraf baik.

Berdasarkan paparan di atas dapat di lihat bahwa terjadi perbaikan dari segi hasil belajar siswa secara positif, artinya siswa mulai terus untuk memperbaiki diri yang merupakan lanjutan dari perbaikan motivasi belajar, karena kemampuan siswa terus terasah setiap pertemuan. hal ini jelas sekali membuktikan bahwa model pembelajaran yang peneliti terapkan mampu meningkatkan gairah belajar, motivasi belajar siswa pada mata pelajaran IPS Sejarah yang bermuara pada hasil belajar.

\section{KESIMPULAN}

Berdasarkan hasil penelitian dan pembahasan, maka dapat di simpulkan hal hal sebagai berikut :

Metode pembelajaran kooperatif tipe Group investigation (GI) dapat di terapkan pada siswa kelas VIII B SMP PGRI 4 Denpasar. metode ini dapat meningkatkan motivasi belajar siswa. hal ini terlihat dari observasi pada siklus I pertemuan I mencapai 28, 21. pertemuan II 30,0 dan pertemuan III mencapai 30,5, tidak hanya sebatas itu peningkatan juga terjadi pada siklus II Pada pertemuan I di mana hasilnya mencapai 31,39 , pertemuan II 34,17 dan pertemuan III 35,25. melihat hasil observasi yang di peroleh artinya antusias siswa dalam mengikuti pembelajaran IPS menjadi semakin baik dengan menggunakan model model pembelajaran.

Penerapan model pembelajaran Kooperatif tipe Group Investigation (GI) dapat meningkatkan hasil belajar pada siswa kelas VIII B SMP PGRI 4 Denpasar. hal ini terlihat pada perbaikan dari segi hasil belajar siswa yang terjadi secara positif, artinya antusias siswa dalam proses pembelajaran pengarah pada pencapaian tujuan pembelajaran dan hasil nilai siswa yang baik, hal ini terlihat pada pelaksanaan tahapan yang peneliti lakukan, di mana pada siklus I mencapai rata rata $82,5 \%$, daya serap $82,5 \%$ dan ketuntasan belajarnya mencapai $72,5 \%$ dan meningkat pada siklus II menjadi rata rata $86,25 \%$, daya serap $82,25 \%$ dan ketuntasan belajarnya mencapai $100 \%$. peningkatan hasil belajar tidak terlepas kemampuan siswa yang terus di asah di tiap pertemuan. hai ini semakin membuktikan bahwa model pembelajaran yang di terapkan mampu meningkatkan semangat belajar pada mata pelajaran IPS Sejarah. 


\section{DAFTAR PUSTAKA}

Dimyati \& M 2013. Belajar dan Pembelajaran. Jakarta : PT Rineka Cipta.

Munadi, Y. 2013. Media Pembelajaran (Sebuah Pendekatan Baru). Jakarta Selatan : REFRENSI (GP Press Group).

Hamalik O. 2011. Kurikulum dan pembelajaran. Jakarta : PT Bumi Aksara

Rusman E. T.2002. Pengantar Ilmu Sejarah Teori Filsafat Sejarah Sejarah Filsafat Dan Iptek, Jakarta PT Rineka Cipta

Senjaya, W. 2008. Strategi Pembelajaran; Berorientasi Standar Proses pendidikan. Jakarta:Kencana Prenada Media Group.

Sukmadinata, NS. 2012. Landasan Psikologi Proses Pendidikan. Bandung : PT Remaja Rosdakarya.

Sutikno M.S. 2014. Metode Dan ModelModel Pembelajaran, Holististica

Sutopo, 2006. Metodologi Penelitian Kualitatif Dasar Teori Dan Penerapannya Dalam Penelitian, Surakarta : UNS

Susanto H. 2014. Seputar pembelajaran sejarah, isu, gagasan dan strategi pembelajaran. Yogyakarta Aswaja Presindo

Suhartono W. P. 2010. Teori Dan Metodologi Sejarah, Yogyakarta Graha Ilmu

Trianto, 2008. Mendesain Pembelajaran Kontekstual, Jakarta : Cerdas Pustaka

2009. Mendesain Model Pembelajaran Inovatif -Progresif, Prenatal Media Grup

Wibowo, B. 2012. Media Pengajaran. Jakarta : Kemendibud.

Widja, I G. 2007. Dasar-dasar Pengembangan Strategi Serta
Metode Pengajaran Sejarah. Jakarta: P2LPTK

Winkel W.S.2012. Psikologi Pengajaran, Yogyakarta Media Abadi

Wineburg. S. 2006. Berpikir Historis, Jakarta Yayasan Obor Indonesia

Yamin, M. 2007. Kiat Membelajarkan Siswa, Jakarta : Gaung Persada Perss

Zainal A, 2014. Model model media dan strategi pembelajaran kontekstual, Bandung YRAMA WIDYA

Dewa N. A. S, I Gede Mahendra D. I Made G. S. 2015 Pengembangan Sistem Informasi Koleksi Museum Bali Berdasarkan Metadata Standar Internasional Committee For Documentation (CIDOC) Jurnal Pendidikan Teknik Informatika Universitas Pendidikan Ganesa. VOL IV No. 5 Tahun 2015

Agus S. 2011.Pemanfaatan Situs Sejarah Sebagai Pengembangan Pembelajaran Sejarah Berbasis Konstruktivisme. Jurnal Ilmiah PGSD Vol.III No.1 April

Deky A. 2014.Pelestarian Situs Cagar Budaya Plawangan Rembang Perspektif Undang-Undang Cagar Budaya,Volume 9. Nomor 2. Januari

Sinaga, N. F. Pengelolaan Situs Cagar Budaya Kota Cina

MedanJom FISIP Vol. 1 No.2 Februari 2015

Nathanael S dan Abdul H. S, 2013. Studi Karakteristik Siswa Slta Di Kota Medan Jurnal Teknologi Pendidikan, Vol.6, No. 2, Oktober 2013, ISSN: 1979-6692

Smith, E. S. 1999. Cognitive Style And Instructional Preferences.

\begin{tabular}{lll} 
University of & Surrey. \\
\hline InternationalJournal of & Surrey
\end{tabular}
Volume 1.0 No__Victory PIPS: 162691 University of Surrey. 